\title{
Cloning of a second non-haem bromoperoxidase gene from Streptomyces aureofaciens ATCC 10762 : sequence analysis, expression in Streptomyces lividans and enzyme purification
}

\author{
Isabelle Pelletier, ${ }^{1}$ Otto Pfeifer, ${ }^{2}$ Josef Altenbuchner ${ }^{1}$ \\ and Karl-Heinz van Pée ${ }^{2}$
}

Author for correspondence: Karl-Heinz van Pée. Tel: +49 711459 2227. Fax: +497114592238.

1 Institut für Industrielle Genetik der Universităt Stuttgart, Allmandring 31, D-70569 Stuttgart, Germany

2 Institut für Mikrobiologie der Universităt Hohenheim, Garbenstraße 30, D-70593 Stuttgart, Germany
The gene for BPO-A1, one of two non-haem bromoperoxidases in the tetracycline and 7-chlorotetracycline producer Streptomyces aureofaciens ATCC 10762, was cloned in the positive selection vector plJ699 and expressed in Streptomyces lividans TK64. The cloned bromoperoxidase was over-produced up to 2800 -fold by the S. lividans TK64 transformant. By taking advantage of the over-production of BPO-A1 and the heat stability of the enzyme, a new and simple purification procedure was developed. Subcloning into the vector pIJ487 and screening of recombinants by a newly developed histochemical assay located the bpoA1 gene on a $2 \cdot 1 \mathrm{~kb} B a m \mathrm{HI}-H i n d I I$ fragment. The nucleotide sequence of the $2.1 \mathrm{~kb}$ fragment was determined; the bpoA1 gene was identified within the sequence on the basis of the biased codon usage of Streptomyces genes and the presence of a nucleotide sequence encoding the N-terminal amino acid sequence obtained from the purified BPO-A1.

Comparison of the deduced primary structure of BPO-A1 with those deduced for the non-haem chloroperoxidase CPO-P from Pseudomonas pyrrocinia and the bromoperoxidase BPO-A2 from S. aureofaciens ATCC 10762 gave amino acid sequence identities of $49 \%$ and $40 \%$, respectively.

Keywords: Streptomyces aureofaciens, bromoperoxidase BPO-A1/A2, non-haem haloperoxidase

\section{INTRODUCTION}

Haloperoxidases are widely distributed enzymes that catalyse the formation of carbon-halogen bonds in the presence of peroxides (e.g. hydrogen peroxide). The majority are haem-type oxidases with protoporphyrin IX as the prosthetic group (Dawson \& Sono, 1987). A second group of haloperoxidases contains vanadium instead of haem (De Boer \& Wever, 1988) and a more recently discovered third group, the bacterial non-haem haloperoxidases, does not require metal ions or any other cofactor (van Pée et al., 1987; Wiesner et al., 1988).

The first bacterial non-haem haloperoxidase, a chloroperoxidase (CPO-P) from Pseudomonas pyrrocinia, was

The GenBank number for the sequence reported in this paper is U01096. detected by Wiesner et al. (1986). Another non-haem haloperoxidase was isolated from the 7-chlorotetracycline and tetracycline producer Streptomyces aureofaciens Tü24 (van Pée et al., 1987). The enzyme isolated as a bromoperoxidase using the monochlorodimedone assay was later shown to be a chloroperoxidase (CPO-T; Burd et al., 1992). Surprisingly S. aureofaciens A TCC 10762, another 7chlorotetracycline and tetracycline producer, possessed two non-haem bromoperoxidases, BPO-A1 and BPO-A2 (Weng et al., 1991). In immunological studies with antiserum raised against $\mathrm{CPO}-\mathrm{T}, \mathrm{BPO}-\mathrm{A} 2$ cross-reacted with CPO-T but not with BPO-A1.

Up to now only very little is known about the reaction mechanism of bacterial non-haem haloperoxidases. Since the bacterial enzymes are able to catalyse the oxidation of halide ions without a prosthetic group or metal ions, one has to assume that the redox reaction takes place at certain 
amino acids of the peptide chain of the protein. Investigations by Haag et al. (1991) using the chloroperoxidases CPO-T from $S$. aureofaciens Tü24 and CPO-P from $P$. pyrrocinia gave the first evidence that a methionine residue is involved in the catalytic cycle of these enzymes.

The genes for BPO-A2 (Pfeifer et al., 1992) and CPO-P (Wolfframm et al., 1993) have been cloned and sequenced. The predicted amino acid sequence of BPO-A2 has only one methionine, which is consequently the only candidate for the postulated 'reactive methionine'. However, CPO$\mathrm{P}$ possesses five methionines, none of them in a position similar to the methionine of BPO-A2 when the sequences are aligned (Wolfframm et al., 1993); thus it was not possible to assign a putative reactive methionine for CPOP.

BPO-A1 is in many respects different from BPO-A2 and CPO-P. Therefore the detection of amino acids conserved in all three proteins might give some information about the active site of bacterial non-haem haloperoxidases. In the following report we describe the cloning and sequencing of $b p o A 1$ and compare the deduced amino acid sequence with those of CPO-P and BPO-A2.

\section{METHODS}

Materials. Hydrogen peroxide $(30 \%)$ was purchased from Merck, and monochlorodimedone from Sigma. Streptavidinalkaline phosphatase complex, restriction endonucleases and bacteriophage T4 DNA ligase were obtained from Gibco/BRI. and calf intestinal alkaline phosphatase (CIAP) was from Boehringer Mannheim. DEAE-Sephacel, Q Sepharose Fast Flow, Chelating Sepharose 6B and molecular mass standards for SDS-PAGE were obtained from Pharmacia. Amicon concentrators and ultrafiltration membranes (Diaflo, YM-10) were obtained from Amicon.

Bacterial strains, vectors and growth of cells. The gene library of $S$. aureofaciens ATCC 10762 was constructed in S. lividans TK64 (Hopwood et al., 1983) using the plasmid pI J699 (Kieser \& Melton, 1988). Subcloning was done in the vector pI J487 (Ward et al., 1986). For DNA sequencing, DNA fragments were inserted into M13mp18 and M13mp19 (Yanisch-Perron et al., 1985) and the phages were propagated in Escherichia coli TG1 (Maniatis et al., 1982). Cultures of S. lividans TK64 harbouring recombinant plasmids were grown in soybean flour-mannitol (SM) medium $(2 \%, w / v$, soybean flour, $2 \%, w / v$, mannitol $)$ at $30^{\circ} \mathrm{C}$. Liquid media contained $5 \mu \mathrm{g}$ thiostrepton $\mathrm{ml}^{-1}$ and agar media $50 \mu \mathrm{g}$ thiostrepton $\mathrm{ml}^{-1}$ (kindly donated by E. R. Squibb and Sons Inc.). E. coli cells were grown in LB medium (Maniatis et al., 1982) at $37^{\circ} \mathrm{C}$. Transformants carrying pUC18 and derivative plasmids were selected on agar media containing $100 \mu \mathrm{g}$ ampicillin $\mathrm{ml}^{-1}, 40 \mu \mathrm{g} \mathrm{X}$-gal ml $\mathrm{m}^{-1}$ and $0 \cdot 2 \mathrm{mM}$ IPTG. Recombinant M13 phages were identified, after infection of $E$. coli TG1, as white plaques in LB soft agar containing X-gal and IPTG.

Molecular biological methods. DNA from $S$. aureofaciens ATCC 10762 was isolated using ' $2 \times$ Kirby mix' as described by Hopwood et al. (1985). Plasmids were isolated by an alkaline lysis method (Kieser, 1984). S. lividans TK64 protoplasts were prepared and transformed as described by Hopwood et al. (1985). Protoplasts were regenerated on R2YE agar plates for $16 \mathrm{~h}$ and transformants were selected by overlaying the plates with $1 \mathrm{ml}$ of a thiostrepton suspension in water $\left(200 \mu \mathrm{g} \mathrm{ml}^{-1}\right)$. Phage DNA of M13 derivatives was extracted as described by Maniatis et al. (1982). DNA digestion with restriction enzymes, dephosphorylation with calf intestinal alkaline phosphatase and ligation were performed as described by Maniatis et al. (1982).

Hybridization studies. Total DNA was digested and separated by agarose gel electrophoresis. Southern blotting, prehybridization and hybridization were performed as described previously (van Pée, 1988) using a Nytran 13N nylon filter (Schleicher \& Schüll). The hybridization conditions were $6 \times \mathrm{SSC}(1 \times \mathrm{SSC}$ is $0.15 \mathrm{M} \mathrm{NaCl}, 0.015 \mathrm{M}$ sodium acetate, $\mathrm{pH}$ $7 \cdot 0$ ) containing $0.7 \%$ skimmed milk and $0.05 \%$ SDS at $68^{\circ} \mathrm{C}$; stringent wash conditions were $0.35 \times \mathrm{SSC}, 1 \% \mathrm{SDS}$ at $60^{\circ} \mathrm{C}$.

The $2.1 \mathrm{~kb}$ BamHI-HindIII fragment from pOP1974, containing the $b p o A 1$ gene used as a hybridization probe, was biotinylated with the nick-translation kit from Gibco/BRL according to the manufacturer's instructions.

Nucleotide sequence analysis. The nucleotide sequence of both strands of the $2.1 \mathrm{~kb}$ BamHI-HindIII fragment containing the $b p o A 1$ gene was determined by the chain termination method (Sanger et al., 1977) in an automated DNA sequencing system (ALF, Pharmacia) with fluorescence-labelled primers as described previously (Pfeifer et al., 1992). The $2 \cdot 1 \mathrm{~kb} \mathrm{BamHI-}$ HindIII fragment and subfragments generated with the restriction enzymes SacI, SalI, KpnI and $B g l \mathrm{II}$ were cloned in M13mp18 and M13mp19, and sequenced with the fluorescencelabelled universal primer. Gaps in the DNA sequence were closed by using additional fluorescence-labelled primers synthesized on a Cyclone Plus DNA synthesizer (Milligen). The DNA sequence was analysed for open reading frames (ORFs) and for the biased codon usage characteristic of Streptomyces genes by using the programs FRAMES and CODON PREFERENCES of the University of Wisconsin Genetics Computer Group (Devereux et al., 1984). For the codon preference program, a codon usage table was generated from eight Streptomyces gene sequences as described by Sedlmeier \& Altenbuchner (1992).

Construction of a genomic library of $\mathbf{S}$. aureofaciens ATCC 10762. Total DNA of $S$. aureofaciens ATCC 10762 was partially digested with Sau3A and fractionated by electrophoresis in an agarose gel. Fragments in the $7-15 \mathrm{~kb}$ range were extracted from the gel ('Tautz \& Renz, 1983) and dephosphorylated. DNA of pIJ699 was digested with $B g / \mathrm{II}$ and DraI, and the fragments were separated on an agarose gel. The $5.0 \mathrm{~kb}$ vector fragment was extracted and ligated with the size-fractionated and dephosphorylated $S$. aureofaciens DNA fragments. The ligation mixture was then used to transform $S$. lividans TK64 protoplasts.

Screening haloperoxidase activities. For 'activity-screening' the thiostrepton-resistant colonies were transferred to SM agar containing thiostrepton and incubated for $7 \mathrm{~d}$ at $30^{\circ} \mathrm{C}$. The colonies from pairs of plates ( 88 colonies) were washed off with liquid SM medium and pooled in individual 1 litre flasks containing $200 \mathrm{ml}$ liquid SM medium plus thiostrepton. The pool cultures were incubated at $30^{\circ} \mathrm{C}$ for $5 \mathrm{~d}$ with shaking. The mycelium was harvested by centrifugation and the cells, suspended in twice their volume of $0.2 \mathrm{M}$ Tris $/ \mathrm{SO}_{4}$ buffer ( $\mathrm{pH} \mathrm{8.3),} \mathrm{were} \mathrm{disrupted} \mathrm{with} \mathrm{a} \mathrm{Branson} \mathrm{sonifier} \mathrm{J} \mathrm{17-A} \mathrm{(twenty}$ 30 s periods, $70 \mathrm{~W}, 4^{\circ} \mathrm{C}$ ). Cell debris was removed by centrifugation for $30 \mathrm{~min}$ at $22100 \mathrm{~g}$. The supernatant solution was dialysed against $0 \cdot 1 \mathrm{M}$ sodium acetate buffer $(\mathrm{pH} \mathrm{5.5)}$ for $15 \mathrm{~h}$. After centrifugation the pellet was discarded and the supernatant 
solution was dialysed against $0.03 \mathrm{M}$ Tris $/ \mathrm{SO}_{4}$ buffer $(\mathrm{pH} 8.3$ ) for $15 \mathrm{~h}$. The dialysed sample was applied to a DEAE-Sephacel column equilibrated with $0.03 \mathrm{M}$ Tris $/ \mathrm{SO}_{4}$ buffer $(\mathrm{pH} \mathrm{8.3)}$. The column was washed with $0.2 \mathrm{M} \mathrm{NaCl}$ in $0.03 \mathrm{M}$ Tris/SO $/ \mathrm{SO}_{4}$ bufer (pH 8.3) and proteins were eluted with $0.7 \mathrm{M} \mathrm{NaCl}$ in the same buffer. Fractions containing bromoperoxidase activity were combined and then incubated for $15 \mathrm{~min}$ at $75^{\circ} \mathrm{C}$. Because the bromoperoxidase from $S$. lividans TK64 is inactivated by the heat treatment, only the bromoperoxidases from $S$. aureofaciens ATCC 10762 remained in solution. To distinguish between BPO-A1 and BPO-A2, samples showing bromoperoxidase activity after the heat treatment were examined by electrophoresis on a non-denaturing polyacrylamide gel. Positive pools were subdivided by further assays into smaller pools and eventually individual colonies were tested.

Subcloning in S. lividans TK64. For subcloning in S. lividans TK64, fragments were isolated from agarose gels and ligated with linearized and phosphatase-treated DNA of pIJ487 and transformed into S. lividans TK64 protoplasts. Colonies containing the bromoperoxidase gene were identified using a newly developed colony-screening procedure.

Colony-screening procedure. For colony-screening, the thiostrepton-resistant colonies were picked onto SM agar plates containing thiostrepton and incubated for $7 \mathrm{~d}$ at $30^{\circ} \mathrm{C}$. The plates were then flooded with lysozyme solution $\left(2 \mathrm{mg} \mathrm{ml}^{-1}\right)$ in $0.3 \mathrm{M}$ sucrose, $25 \mathrm{mM}$ Tris $/ \mathrm{HCl}$ ( $\mathrm{pH} \mathrm{8.0)}, 25 \mathrm{mM}$ EDTA $(\mathrm{pH} 8.0), 5 \%(\mathrm{w} / \mathrm{v})$ Triton $\mathrm{X}-100$ and incubated for $1 \mathrm{~h}$ at $37^{\circ} \mathrm{C}$. The lysozyme solution was discarded, the plates washed once with water and afterwards flooded with $1 \mathrm{M}$ sodium acetate buffer ( $\mathrm{pH} 5.5$ ), $0.002 \%$ phenol red, $1 \mathrm{M}$ sodium bromide, $10 \mathrm{mM}$ sodium azide, and $17.6 \mathrm{mM} \mathrm{H}_{2} \mathrm{O}_{2}$. Positive clones were identified by a blue halo around the colony, or as blue colonies after longer incubation.

Purification of BPO-A1 from recombinant S. lividans TK64 clones. All steps of the purification were performed at $4{ }^{\circ} \mathrm{C}$ unless otherwise stated. $S$. lividans TK64 harbouring plasmids encoding BPO-A1 was grown for $3 \mathrm{~d}$; the cells were harvested $(40 \mathrm{~g}$ wet $\mathrm{wt})$, resuspended in $80 \mathrm{ml}$ of $0 \cdot 1 \mathrm{M}$ ammonium acetate buffer (pH 6.8) and disrupted with a Branson sonifier J 17-A (twenty $30 \mathrm{~s}$ periods, $70 \mathrm{~W}, 4^{\circ} \mathrm{C}$ ). Cell debris was removed by centrifugation for $30 \mathrm{~min}$ at $22100 \mathrm{~g}$. The supernatant solution was incubated at $75^{\circ} \mathrm{C}$ for $15 \mathrm{~min}$ and precipitated proteins were removed by centrifugation. The heat-treated extract was applied at room temperature to a column $(2.6 \times 7.5 \mathrm{~cm})$ of $\mathrm{Q}$ Sepharose Fast Flow, previously equilibrated with $20 \mathrm{mM}$ ammonium acetate buffer ( $\mathrm{pH}$ 6.8). After the column had been washed with 2 column volumes of the same buffer, the BPO-A1 activity was eluted with a linear gradient of $300 \mathrm{ml} \mathrm{0-1} \mathrm{M} \mathrm{NaCl}$ in the washing buffer. Fractions $(3 \mathrm{ml})$ with activities more than $20 \%$ of the maximum were pooled and concentrated to $2-3 \mathrm{ml}$ using an Amicon concentrator with a YM-10 membrane. The buffer was then changed by washing the concentrated solution twice with $20 \mathrm{mM}$ potassium phosphate buffer $(\mathrm{pH} \mathrm{7 \cdot 0})$ in the Amicon apparatus. The concentrated solution was applied at room temperature to a Chelating Sepharose $6 \mathrm{~B}$ column $(2 \cdot 6 \times$ $10 \mathrm{~cm}$ ) loaded with $\mathrm{CuSO}_{4}\left(3 \mathrm{mg} \mathrm{ml}^{-1}\right.$ in $\left.\mathrm{H}_{2} \mathrm{O}\right)$ to about $\frac{2}{3}$ of its capacity and equilibrated with $20 \mathrm{mM}$ potassium phosphate buffer ( $\mathrm{pH} 7 \cdot 0)$. Since BPO-A1 did not bind to the gel, it was eluted with the same buffer. Fractions $(3 \mathrm{ml})$ with activities more than $20 \%$ of the maximum were combined and concentrated by ultrafiltration over a YM-10 membrane.

Enzyme assays. Brominating activity was measured spectro- photometrically as described previously (Weng et al., 1991). Protein concentration was determined by the Lowry method using bovine serum albumin as a standard.

Electrophoresis. For electrophoresis of native enzymes, $7 \cdot 5 \%$ $(\mathrm{w} / \mathrm{v})$ polyacrylamide gels ( $\mathrm{pH} 7 \cdot 5$ ) were used (Maurer, 1964). PAGE in the presence of $0.1 \%$ SDS was done according to Schägger \& von Jagow (1987). Proteins of the low molecular mass calibration kit (Pharmacia) were used as standards. Gels were stained for proteins with Serva Blue R. Brominating activity was detected on native PAGE by the conversion of phenol red to bromophenol blue (Weng et al., 1991).

\section{RESULTS}

\section{Cloning and expression of the bpoA1 gene from $S$. aureofaciens ATCC 10762}

The gene encoding BPO-A1 from S. aureofaciens ATCC 10762 was isolated from a genomic library constructed in the plasmid pIJ699. Screening of 4400 thiostreptonresistant colonies using the activity selection technique described in Methods gave two positive clones containing an insert fragment of $7.4 \mathrm{~kb}$ (pOP1974) or $7.9 \mathrm{~kb}$ (pOP1979). No clone containing bpo A2 was isolated.

\section{Restriction mapping and subcloning}

Plasmids pOP1974 and pOP1979 exhibited nearly identical restriction patterns. Therefore only pOP1974 was used for further investigations. A partial restriction map is shown in Fig. 1. The insert contained no restriction sites for the endonucleases $X b a \mathrm{I}$ and $X b o \mathrm{I}$. For subcloning, pOP1974 was digested with BamHI and BamHI-HindIII. Only the $3.8 \mathrm{~kb}$ Bam HI fragment (pOP1738) and the $2 \cdot 1 \mathrm{~kb}$ Bam HI-HindIII fragment (pOP1721) gave bromoperoxidase activity when subcloned in pIJ487.

\section{Southern blotting of total DNA digests}

To confirm the origin of the cloned bromoperoxidase gene, Southern hybridization of the $2 \cdot 1 \mathrm{~kb}$ BamHIHindIII fragment of pOP1974 was performed with Bam HI-HindIII-digested DNA from S. aureofaciens ATCC 10762 and $S$. lividans TK64. The biotinylated $2 \cdot 1 \mathrm{~kb}$

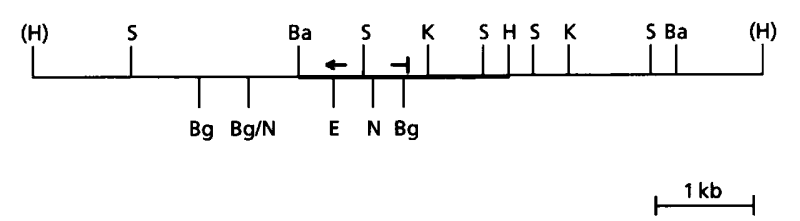

Fig. 1. Partial restriction map of the $7.4 \mathrm{~kb}$ fragment of pOP1974, containing the bpoA1 gene from $S$. aureofaciens ATCC 10762. The abbreviations $B a, B g, E, H, K, N, S$ and $X$ indicate BamHI, Bglll, EcoRl, HindllI, Kpnl, Ncol, Sstl and Xhol, respectively. The $2 \cdot 1 \mathrm{~kb} B a m \mathrm{HI}-$ Hind III fragment which has been sequenced is marked with a bold line. The arrow indicates the location of the bpoA1 gene, determined from the sequence data. 


\section{HindIII}

1 AAGCTTGCGGCCGTTGCGTCGCCACCCTCCTGGCCGCCGGCTTCGGTGTGACCACCGCCGGCAGCGCCTCGGCCGCGACGTCCCCGAGC

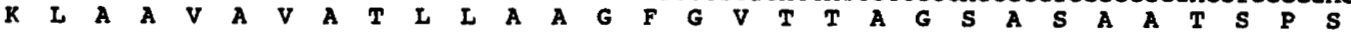

91 AgCrCTGCGGCGGCTACAGCACCAGCGAGCCGATGCTCTCCCAGGACGACAGCGGTGACGCGGTCAAGGCCTTGCAGTGCGAGCTCTAC

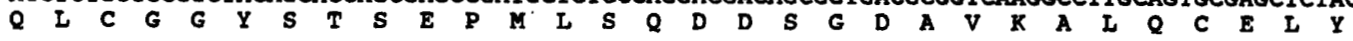

$\operatorname{San}$

181 AACTCCCTCGCCTACATGGGCCCGGACGTCGACGGGTACTTCGGCCCCAAGACCCTCGCCGCGGTGCAGAGTTCCAGACCTGCACCGGT

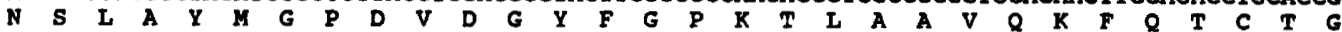

271 CTCAAGCCCGACGGCATCGTCGGCCCGCTGACCTGGGCCAAGCTGGACTACCAGAGCAGCCAGGGCACCACCCCGGTCTGGTGCTAGGCC

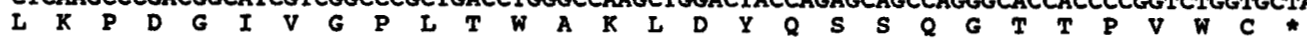

NruI

361 CCACCCCTGGGGCCCGTACGCCCCGAATGACCACCCAGCTCGCGAACTGAACGCCTCCTCCGCCCTCTTCCCCACCCCCTTCAACCTGGA Sall

451 CGTCGACGGGCAGTTCGGCAAGAACACCCTCGCCGCGGTGAAGAGGTTCCAGGTGTGCGTCAAGCTCCCGGCCGACGGCATCGTCGGCCC

541 GAACACCTGGTCCGAGTGGACTTCTACGCCACCGCGTGGAAAGGGCGACCTGCTGACGATCCGTCGCCGCAGGGGACTGACGAAGACG

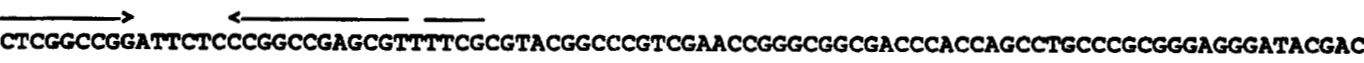
CGTACTCGTTGCCAGCCGTTCGTTGCCCCGTCCTCGTCAGGAGCACGGCCGCCGGTAGGGGTGGTGGCCGGCGTACTTCTTCCACTGGCT

811 CTCGGGCACCGGGTACCGTGGCGCCTCCAGGCGGCCATGAGGTCGATCTCCGTAGGTCCTPGAGGCAGCTGTCGTCGTGCTTCGGCGA

901 GTGTCGGCTCGATCGGCGGGCGGGACCACCCCGTCACGTAGGCCATCTGGGGTTCGGCGCTTGCGCCTGGTGCGGGCATGCGTTCGGCT G- - - - Smal - RBs

991 GGCAAGCGGATGCCCGAGCATCCCTCTTCCTCCCGGGCCACCCAACACCTTATGGAGACCACATECCCATCTGCACCACCCGCGACGGTE Bgal

1081 TCGAGATCTTCTACAAGGACTGGGGCCAGGGACGTCCCGTGGTGTTCATCCACGGCTGGCCGCTCAACGGCGACGCCTGGCAGGACCAGC

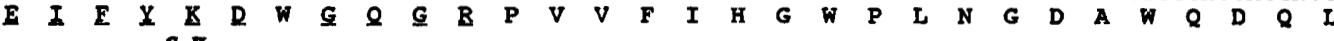
Sall

1171 TCAAGGCCGTCGTCGACGCCGGATACCGCGGAATCGCGCACGACCGCCGCGGCCACGGACACTCCACGCCCGTCTGGGACGGCTACGACT

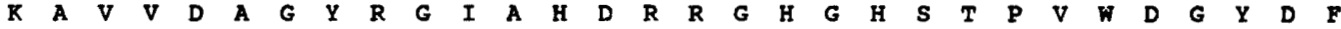
Ncol

1261 TCGACACCTTCGCCGACGACCTCAACGACCTGCTCACCGACCTCGACCTGCGAGATGTCACCCTGGTCGCGCACTCCATGGGTGGCGGCG

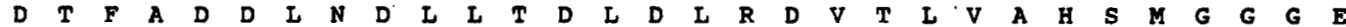
SacI

1351 AGCTCGCGCGCTACGTCGGCCGACACGGCACGGGGCGGCTGCGCTCGGCGGTGCTGCTGTCCGCCATCCCGCCGGTGATGATCAAATCTG $\begin{array}{lllllllllllllllllllllllllllllllll}I & A & R & Y & V & G & R & H & G & T & G & R & L & R & S & A & V & I & L & S & A & I & P & P & V & M & I & K & S & D\end{array}$

1441 ACAAGAATCCCGACGGCGTGCCGGACGAGGTGTTCGACGCACTCAAGAACGGCGTCCTCACCGAGCGCTCCCAGTTCTGGAAGACACTG

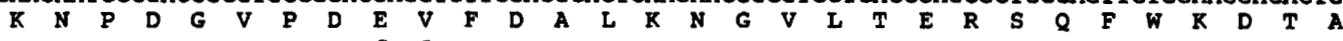
Smal

1531 CGGAGGGCTTCTTCTCCGCCAACCGCCCCGGGACAAGGTCACCCAGGGCAACAAGGATGCCTTCTGGTACATGGCGATGGCGCAGACCA E G F F S A N R P G N K V T Q

1621 TCGAAGGCGGCGTGCGGTGCGTGGACGCCTTCGGTTACACCGACTTCACCGAAGACCTGAAGAGTTCGACATTCCCACCCTGGTGGTGC

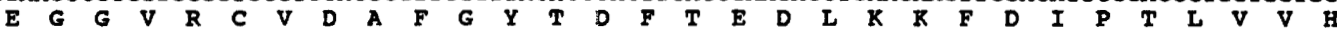

1711 ACGGCGACGACGACCAGGTCGTGCCCATCGACGCCACCGGCCGCAAGTCCGCCCAGATCATCCCGAACGCCGAGCTGAAGGTGTACGAGG

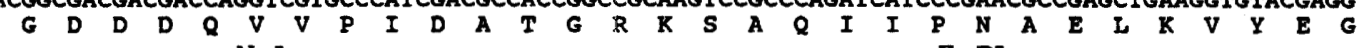
Nrul

1801 GCAGCTCCCACGGCATCGCGATGGTGCCGGGCACAAGGAGAGTTCAACCGGGACTGTTGGATTCCTCAACAAGTAGAAGGCCCAGG

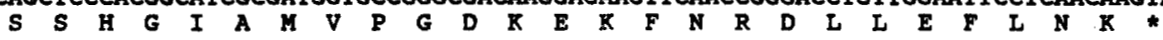

1891 CGAAGTCTCAGCCGACCCGGACAGCCGCAAGGTCTTACTCGCCTTCGCCCAGGACGACGAAGGAACGGCCGCCGCCCGAGCCCTCGTACT

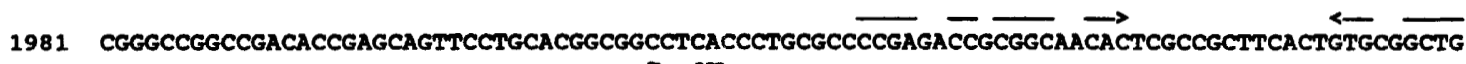
2071 GEGGTTCGGTTCCTGGTTCGGCATGCGGGCCGGGAGGATCC

Fig. 2. Nucleotide sequence of the $2 \cdot 1 \mathrm{~kb}$ BamHI-Hind!ll fragment containing the bpoAl gene and the deduced amino acid sequence of BPO-A1. The sequence of amino acids underlined was determined by Edman degradation. The putative Shine-Dalgarno sequence of bpoA1 and the potential promoter region are underlined. A palindromic sequence that overlaps the promoter regions and might play a role in the regulation of bpoA1 expression is also indicated. An imperfect inverted repeat in the $3^{\prime}$ flanking region of bpoA1 presumably encodes a transcriptional terminator. A truncated ORF called orf 1 is upstream of bPOA1; the 118 amino acids of the C-terminal part of the protein ORF1 are given below the nucleotide sequence. In the intergenic region, a 17 bp palindromic sequence is indicated.

fragment of pOP1974 hybridized with a single $2 \cdot 1 \mathrm{~kb}$ fragment of total DNA from S. aureofaciens ATCC 10762 but not with $S$. lividans TK64 DNA. These results demonstrated that the cloned bromoperoxidase gene originated from the DNA of S. aureofaciens ATCC 10762 and not from $S$. lividans and that $b p o A 1$ is not similar in its 
1 2 3 $10^{-3} \times$
$M_{r}$ $-94$ $-67$

Fig. 3. SDS-PAGE of the bromoperoxidase produced by $S$. lividans TK64 harbouring POP1738, BPO-A1 and BPO-A2 from S. aureofaciens ATCC 10762. Lanes: $1,3.2 \mu \mathrm{g}$ BPO-A2; $2,3.2 \mu \mathrm{g}$ BPO-A1 produced by S. lividans TK64(pOP1738); $3,3 \cdot 2 \mu \mathrm{g}$ BPO$A 1 ; 4$, SDS marker proteins. The gel was stained with Serva Blue R.

DNA sequence to $b p o A 2$ despite its presence in the same strain (Pfeifer et al., 1992). Furthermore no hybridization signals were found with the DNA of S. aureofaciens Tü24 and $P$. pyrrocinia. These species produce the chloroperoxidases CPO-T and CPO-P, respectively, which belong to the same group of non-haem haloperoxidases as BPO-A1.

\section{Nucleotide sequence analysis}

The nucleotide sequence of both strands of the $2 \cdot 1 \mathrm{~kb}$ Bam HI-HindIII fragment was determined after subfragments with a size of about $500 \mathrm{bp}$ had been cloned in M13mp18 and M13mp19. Only one complete ORF matching the very biased codon usage of Streptomyces was present (Fig. 2). This $825 \mathrm{bp} \mathrm{ORF}$ extended from position 1053 to 1878 downstream of the HindIII site and encoded a predicted protein of 275 amino acids. The calculated $M_{\mathrm{r}}$ of 30475 for the predicted polypeptide is in good agreement with the size of the BPO-A1 subunits $\left(M_{\mathrm{r}} 31000\right)$ as determined by SDS-PAGE (Fig. 3). Furthermore, the N-terminal amino acids of the deduced polypeptide are identical with the $\mathrm{N}$-terminal amino acid sequence of BPO-A1 determined by Edman degradation of BPO-A1 purified from $S$. aureofaciens (Weng et al., 1991). This clearly identifies the product of the cloned gene as BPO-A1. Upstream of the ORF a potential ribosome-binding site as well as a promoter $(-35$ and -10 regions) of the $E$. coli $\mathrm{E} \sigma^{70}$ type were identified by
DNA sequence comparison. An imperfect inverted repeat overlaps the putative promoter sequence and may be involved in the regulation of $b p o A 1$. Another inverted repeat was found at the end of the gene, but its potential to form a stem-loop structure might be too weak for it to act as a transcriptional terminator. When the amino acid sequence of BPO-A1 was aligned with those of BPO-A2 and CPO-P (Fig. 4), pairwise comparison gave $40 \%$ amino acid identity for the BPO-A1/BPO-A2 pair, $49 \%$ for the BPO-A1/CPO-P pair, and $38 \%$ identity between BPO-A2 and CPO-P. The quite similar size of the three haloperoxidases and the high percentage of identical amino acids in their primary sequence indicate that they derive from a common ancestor. Furthermore, BPO-A1 seems to be more related to CPO-P than to BPO-A2.

A second ORF, truncated at its $5^{\prime}$-end and displaying the typical Streptomyces codon usage, was identified on the $2.1 \mathrm{~kb}$ fragment. This incomplete ORF ends 700 nucleotides upstream of the $b p o A 1$ gene at position 357 (Fig. 2), and encodes the last 118 amino acids from the $\mathrm{C}$-terminal part of a putative protein called ORF1. It displays an overall amino acid identity of $34 \%$ with the C-terminal end of CwlA, an autolytic amidase from Bacillus subtilis (Foster, 1991). As shown in Fig. 5, many of the last 50 amino acids of ORF1 and CwlA are conserved in two other autolytic lysozymes, LysC from Clostridium acetobutylicum (Croux \& Garcia, 1991) and Cbpm, the muramoyl-pentapeptide carboxypeptidase from Streptomyces albus (Joris et al., 1983). From the sequence similarity of these regions in LysC and Cbpm, Croux \& Garcia (1991) have postulated that the conserved domain is involved in recognition of the peptidoglycan substrate of these enzymes. The distance between the putative autolysin gene orf 1 and $b p o A 1$ makes it unlikely that they are part of an operon. Furthermore, an inverted repeat with a calculated $\Delta G$ of $-45 \mathrm{kcal} \mathrm{mol}^{-1}$ at position 622-662 between the genes may terminate transcription of the autolysin gene.

\section{Purification of BPO-A1 from S. lividans TK64 (pOP1738)}

S. lividans TK64 containing pOP1738 produces the bromoperoxidase at high levels. When the purification method previously described for BPO-A2 (Pfeifer $e t$ al., 1992) was used, no homogeneous protein was obtained. Therefore the purification procedure summarized in Table 1 was developed. The specific activity $\left(46 \mathrm{U} \mathrm{mg}^{-1}\right.$ ) of the final product indicated a 51 -fold purification. The bromoperoxidase isolated from $S$. lividans TK64(pOP1738) was identical to BPO-A1 from S. aureofaciens ATCC 10762 in its electrophoretic mobility on denaturing (Fig. 3) and non-denaturing polyacrylamide gels; it differed from BPO-A2 on native polyacrylamide gels (Fig. 6). When the gels were stained for brominating activity (Fig. 6a), several active bands could be seen. This is due to the formation of aggregates in buffers of low salt concentration. However, these bands could be detected only using activity staining, which is more sensitive than protein staining with Coomassie blue. 


\begin{tabular}{|c|c|c|c|c|c|c|}
\hline $\begin{array}{l}\mathrm{BPO}-\mathrm{A} 1 \\
\mathrm{BPO}-\mathrm{A} 2 \\
\mathrm{CPO}-\mathrm{P}\end{array}$ & & $\begin{array}{l}\text { MPICTTRDG. } \\
\text { MPFITVGQEN } \\
\text { MPYVTTKDN }\end{array}$ & $\begin{array}{l}\ldots \text { VEIFYKD } \\
\text { STSIDLYYED } \\
\ldots \text {. VEIFYKD }\end{array}$ & $\begin{array}{l}\text { WGQ . . GRPVV } \\
\text { HGT . . GQPVV } \\
\text { WGPKDAQPIV }\end{array}$ & $\begin{array}{l}\text { FIHGWPLNGD } \\
\text { LIHGFPLSGH } \\
\text { FHHGWPLSGD }\end{array}$ & $\begin{array}{l}\text { AWQDQLKAVV } \\
\text { SWERQSAALL } \\
\text { DWDAQMLFFV }\end{array}$ \\
\hline & 50 & $\star \star \star \star \star *+*$ & $\star \star \star *+* \quad *$ & $+* * *$ & * & $\star \star+$ \\
\hline $\begin{array}{l}\text { BPO-A } 1 \\
\text { BPO-A2 } \\
\text { CPO-P }\end{array}$ & & $\begin{array}{l}\text { DAGYRGIAHD } \\
\text { DAGYRVITYD } \\
\text { QKGYRVIAHD }\end{array}$ & $\begin{array}{l}\text { RRGHGHSTPV } \\
\text { RRGFGQSSQP } \\
\text { RRGHGRSAQV }\end{array}$ & $\begin{array}{l}\text { WDGYDFDTFA } \\
\text { TTGYDYDTFA } \\
\text { SDGHDYDHYA }\end{array}$ & $\begin{array}{l}\text { DDLNDLLTDL } \\
\text { ADLNTVLETL } \\
\text { ADAFAVVEAL }\end{array}$ & $\begin{array}{l}\text { DLRDVTLVAH } \\
\text { DLQDAVLVGF } \\
\text { DLRNAVHIGH }\end{array}$ \\
\hline & 100 & 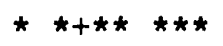 & $+*$ & $+++t+$ & $+\star+\star *$ & 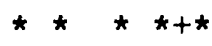 \\
\hline $\begin{array}{l}\text { BPO-A1 } \\
\text { BPO-A2 } \\
\text { CPO-P }\end{array}$ & & $\begin{array}{l}\text { SYGGGEIAARY } \\
\text { SMGTGEVARY } \\
\text { STGGGEVARY }\end{array}$ & $\begin{array}{l}\text { VGRHG. . TGR } \\
\text { VSSYG. . TAR } \\
\text { VANDGQPAGR }\end{array}$ & $\begin{array}{l}\text { LRSAVLLSAI } \\
\text { IAKVAFLASL } \\
\text { VAKAVLVSAV }\end{array}$ & $\begin{array}{l}\text { PPVMIKSDKN } \\
\text { EPFLLKTDDN } \\
\text { PPLMLKTESN }\end{array}$ & $\begin{array}{l}\text { PDGV. PDEVF } \\
\text { PDGAAPQEFF } \\
\text { PEGL. PIEVF }\end{array}$ \\
\hline & 150 & $\star$ & $\star+*$ & $+*$ & +++ & + \\
\hline $\begin{array}{l}\mathrm{BPO}-\mathrm{A} 1 \\
\mathrm{BPO}-\mathrm{A} 2 \\
\mathrm{CPO}-\mathrm{P}\end{array}$ & & $\begin{array}{l}\text { DALKNGVLTE } \\
\text { DGIVAAVKAD } \\
\text { DGFRKALADN }\end{array}$ & $\begin{array}{l}\text { RSQFWKDTAE } \\
\text { RYAFYTGFFN } \\
\text { RAQFFLDVPT }\end{array}$ & $\begin{array}{l}\text { G.FFSANRP. } \\
\text { D.FYNLDENL } \\
\text { GPFYGFNRA. }\end{array}$ & $\begin{array}{l}\text { GNKVTQGNKD } \\
\text { GTRISEEAVR } \\
\text { GATVHQGVIR }\end{array}$ & $\begin{array}{l}\text { AFWYMAMAQT } \\
\text { NSWNTAASGG } \\
\text { NWWRQGMEGS }\end{array}$ \\
\hline & 200 & + & $\star *++*+$ & $\star+*+$ & $* *+*++* *$ & ++ \\
\hline $\begin{array}{l}\mathrm{BPO}-\mathrm{A} 1 \\
\mathrm{BPO}-\mathrm{A} 2 \\
\mathrm{CPO}-\mathrm{P}\end{array}$ & & $\begin{array}{l}\text { IEGGVRCVDA } \\
\text { FFAAAAAPTT } \\
\text { AKAHYDGIKA }\end{array}$ & $\begin{array}{l}\text { FGYTDFTEDL } \\
\text { W. YTDFRADI } \\
\text { FSETDQTEDL }\end{array}$ & $\begin{array}{l}\text { KKFDIPTLVV } \\
\text { PRIDVPALIL } \\
\text { KSITVPTLVL }\end{array}$ & $\begin{array}{l}\text { HGDDDQVVPI } \\
\text { HGTGDRTLPI } \\
\text { HGEDDQIVPI }\end{array}$ & $\begin{array}{l}\text { DATGRKSAQI } \\
\text { ENTARVFHKA } \\
\text { ADAALKSIKL }\end{array}$ \\
\hline & 250 & +++ & $\star+\star \star *$ & $\star+*$ & * * & \\
\hline $\begin{array}{l}\mathrm{BPO}-\mathrm{A} 1 \\
\mathrm{BPO}-\mathrm{A} 2 \\
\mathrm{CPO}-\mathrm{P}\end{array}$ & & $\begin{array}{l}\text { IPNAELKVYE } \\
\text { LPSAEYVEVE } \\
\text { LQNGTLKTYP }\end{array}$ & $\begin{array}{l}\text { GSSHGIAMVP } \\
\text { GAPHG . . LLW } \\
\text { GYSHG. . MLT }\end{array}$ & $\begin{array}{l}\text { GDKEKFNRDL } \\
\text { THAEEVNTAL } \\
\text { VNADVLNADL }\end{array}$ & $\begin{array}{l}\text { LEFLNK } \\
\text { LAFLAK } \\
\text { LAFVQA }\end{array}$ & \\
\hline
\end{tabular}

Fig. 4. Alignment of the deduced amino acid sequence of BPO-A1 with the sequences of BPO-A2 from $S$. aureofaciens ATCC 10762 and CPO-P from P. pyrrocinia. Amino acids identical in the three enzymes at corresponding positions are marked with an asterisk $\left(^{*}\right)$ above the alignment, and those conserved in two sequences with a $+.8 P O-A 2$ and CPO-P have 278 amino acids, whereas BPO-A1 contains 275 . The methionines are in bold letters.

Table 1. Purification of bromoperoxidase BPO-A1 from S. lividans TK64(pOP1738)

\begin{tabular}{|c|c|c|c|c|}
\hline Step & $\begin{array}{c}\text { Total } \\
\text { protein } \\
\text { (mg) }\end{array}$ & $\begin{array}{c}\text { Total } \\
\text { activity } \\
\text { (U) }\end{array}$ & $\begin{array}{c}\text { Sp. act. } \\
{[\mathrm{U}(\mathrm{mg}} \\
\left.\text { protein) }{ }^{-1}\right]\end{array}$ & $\begin{array}{c}\text { Yield } \\
(\%)\end{array}$ \\
\hline Crude extract* & $480 \cdot 0$ & 440 & $0 \cdot 9$ & 100 \\
\hline Heat treatment & $328 \cdot 0$ & 352 & $1 \cdot 1$ & 80 \\
\hline Q Sepharose Fast Flow & $38 \cdot 8$ & 310 & $8 \cdot 0$ & 70 \\
\hline Chelating Sepharose 6B & $5 \cdot 7$ & 260 & $46 \cdot 0$ & 60 \\
\hline
\end{tabular}

* Prepared from $40 \mathrm{~g}$ of cells (wet wt).

\section{DISCUSSION}

The $b p o A 1$ gene of $S$. aureofaciens ATCC 10762 was cloned by constructing a genomic library of $S$. aureofaciens ATCC 10762 in S. lividans TK64 using the plasmid pIJ699. Screening of 4400 thiostrepton-resistant colonies using an activity selection technique yielded two positive clones, one containing an insert fragment of $7.4 \mathrm{~kb}$ (in pOP1974), and the other of $7.9 \mathrm{~kb}$ (in pOP1979). These contained very similar regions of DNA. Comparisons with the two bromoperoxidases of S. aureofaciens ATCC 10762 showed that the product of the cloned gene was identical to BPOA1.

The coding sequence for BPO-A1 was located by 
(a)

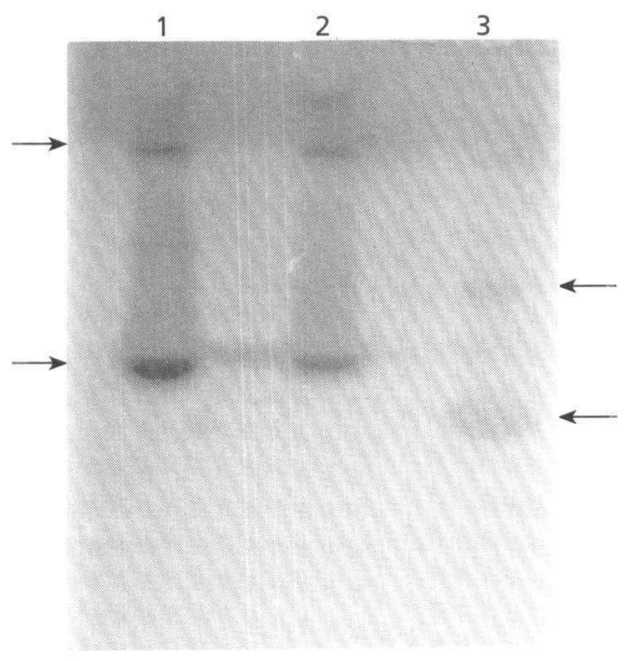

(b)

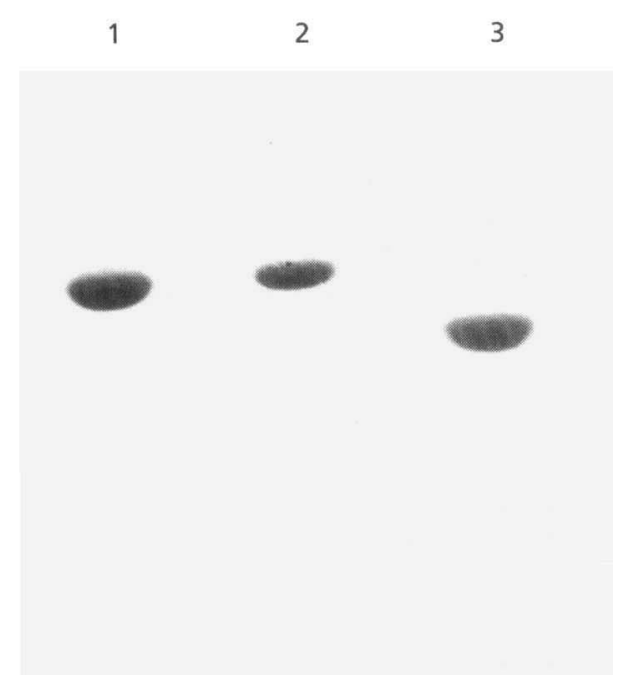

Fig. 6. Comparison by native PAGE of the bromoperoxidase produced by S. lividans TK64 harbouring pOP1738 with BPO-A1 and BPO-A2 from S. aureofaciens ATCC 10762. (a) Activity staining with phenol red for brominating activity. The bands showing brominating activity are marked with arrows. (b) Protein staining with Serva Blue R. Lanes: $1,3.2 \mu \mathrm{g}$ BPO-A1 from S. lividans TK64(pOP1738); $2,2 \mu \mathrm{g}$ BPO-A1; 3, $2 \mu \mathrm{g}$ BPOA2.

subcloning of the $7 \cdot 4 \mathrm{~kb}$ fragment from pOP1974 in the plasmid pIJ487. The $2 \cdot 1 \mathrm{~kb}$ Bam HI-HindIII fragment (pOP1721) contained all the information needed for BPOA1 expression in S. lividans TK64.

DNA sequence analysis established that the regions flanking $b p o A 1$ and $b p o A 2$ are quite different. Pfeifer $e t a l$. (1992) reported an ORF with the opposite orientation immediately upstream of $b p o A 2$; until now no function for this putative gene has been determined. In the neighbourhood of $b p o A 1$, the nearest $\mathrm{ORF}($ orf 1 ) that can be recognized based on the highly biased codon usage of Streptomyces has the same orientation as $b p o A 1$ and terminates $700 \mathrm{bp}$ upstream of this gene. Furthermore, it appears to encode a protein sharing sequence similarity with autolysins. The distance between orf 1 and $b p o A 1$, the presence of a potential transcriptional terminator in the non-coding region between orf 1 and $b p o A 1$ and the presence of a putative promoter region upstream of $b p o A 1$ make it unlikely that these genes are part of the same operon. In the non-coding sequences downstream of the genes, $b p \circ A 2$ showed three very distinct inverted repeats (Pfeifer et al., 1992), whereas $b p o A 1$ has a single quite imperfect inverted repeat.

The putative promoter regions of $b p o A 1$ and $b p o A 2$ have no apparent sequence similarities, but the coding sequences share $62 \%$ identical nucleotides. A comparison of the amino acid sequences of the enzymes reveals $40 \%$ identity, indicating a probable evolutionary relationship. However, BPO-A1 displays an even higher level of identical amino acids $(49 \%)$ with CPO-P from $P$. pyrrocinia.

Of special interest was the distribution of the methionine residues in BPO-A1. Incubation of CPO-T from $S$. aureofaciens $\mathrm{Tü} 24$ and $\mathrm{CPO}-\mathrm{P}$ from $P$. pyrrocinia in the presence of cyanide, bromide and hydrogen peroxide leads to cleavage of the proteins into two peptides. Based on this observation, Haag et al. (1991) have postulated that a methionine is involved in the catalytic cycle of these haloperoxidases. In contrast, BPO-A2 contains, in addition to the formyl-methionine, only one methionine residue at position 102 within the overall primary sequence, whereas CPO-P contains five methionine residues; none of these methionines is at the position homologous to Met102. BPO-A1 also contains five methionine residues, but in this case one is exactly equivalent to Met102, in a region highly conserved in all haloperoxidases. Site-directed mutagenesis, now in progress, should clarify the catalytic role of this methionine in halogenation.

The function of BPO-A1 in the cell remains unclear. If haloperoxidases are responsible for the chlorination step in the biosynthesis of 7-chlorotetracycline, this task is very likely fulfilled by $\mathrm{BPO}-\mathrm{A} 2$ because an immunologically identical enzyme is present in $S$. aureofaciens Tü24, whereas a counterpart to BPO-A1 is absent. We can assume that $S$. aureofaciens ATCC 10762 produces another halogenated compound not yet identified, or that the enzyme has lost its function as part of a biosynthetic pathway due to DNA rearrangement.

The over-production of BPO-A1 by S. lividans TK64 is probably due to the high copy number of pIJ487 (Ward $e t$ al., 1986), the resistance of bacterial non-haem haloperoxidases to proteolysis (K.-H. van Pée, unpublished results) and the lack of a regulatory element on the plasmid. The over-production and remarkable heat stability of the enzyme led to a simple purification procedure with very high yields. S. lividans TK64 harbouring pOP1738 produces $143 \mu \mathrm{g}$ of homogeneous bromo- 
peroxidase per $1 \mathrm{~g}$ (wet wt) of cells. To isolate the same amount of enzyme from S. aureofaciens ATCC 10762, $2800 \mathrm{~g}$ of cells would be needed (Weng et al., 1991). The availability of the bromoperoxidase will allow experiments yielding further insights into the mechanism of bacterial non-haem haloperoxidase reactions. Crystallization and $\mathrm{X}$-ray analysis should give an opportunity for comparative studies with BPO-A2, which has already been crystallized and from which preliminary X-ray data have already been obtained (Sobek et al., 1991).

\section{ACKNOWLEDGEMENTS}

This work was supported by the Deutsche Forschungsgemeinschaft (O. Pfeifer \& I. Pelletier), by a Heisenberg grant from the Deutsche Forschungsgemeinschaft (K.-H. van Pée), by the Bundesministerium für Forschung und Technologie (FRG) under the contract $0319416 \mathrm{~A}$, and by the Fonds der Chemischen Industrie.

\section{REFERENCES}

Burd, V. N., van Pée, K.-H., Lingens, F. \& Voskoboev, A. (1992). Enzymatic chlorination of 2-(3,5-dibromo-2-methoxyphenyl)pyrrole. Bioorg Khim 18, 1002-1006.

Croux, C. \& Garcia, J. L. (1991). Sequence of the $l y c$ gene encoding the autolytic lysozyme from Clostridium acetobutylicum ATCC 824: comparison with other lytic enzymes. Gene 104, 25-31.

Dawson, J. H. \& Sono, M. (1987). Cytochrome P-450 and chloroperoxidase: thiolate ligated heme enzymes. Spectroscopic determination of their active site structures and mechanistic implications of thiolate ligation. Chem $\operatorname{Rev} 87,1255-1276$.

De Boer, E. \& Wever, R. (1988). The reaction mechanism of the novel vanadium bromoperoxidase. J Biol Chem 263, 12326-12332.

Devereux, J., Haeberli, P. \& Smithies, O. (1984). A comprehensive set of sequence analysis programs for the VAX. Nucleic Acids Res 12, 387-395.

Foster, S. J. (1991). Cloning, expression, sequence analysis and biochemical characterization of an autolytic amidase from Bacillus subtilis 168. J Gen Microbiol 137, 1987-1998.

Haag, T., Lingens, F. \& van Pée, K.-H. (1991). A metal ion and cofactor-independent enzymatic redox reaction: halogenation by bacterial non-heme haloperoxidases. Angew Chem Int Ed Engl 30, 1487-1488.

Hopwood, D. A., Kieser, T., Wright, H. M. \& Bibb, M. J. (1983). Plasmids, recombination and chromosome mapping in Streptomyces lividans 66. J Gen Microbiol 129, 2257-2269.

Hopwood, D. A., Bibb, M. J., Chater, K. F., Kieser, T., Bruton, C. J., Kieser, H. M., Lydiate, D. J., Smith, C. P., Ward, J. M. \& Schrempf, H. (1985). Genetic Manipulation of Streptomyces - a Laboratory Manual. Norwich: John Innes Foundation.

Joris, B., Beemen, J. V., Casagrande, F., Gerday, C., Frere, J.-M. \& Ghuysen, J.-M. (1983). The complete amino acid sequence of the $\mathrm{Zn}^{2+}$-containing D-alanyl-D-alanine-cleaving carboxypeptidase of Streptomyces albus G. Eur J Biochem 130, 53-69.

Kieser, T. (1984). Factors affecting the isolation of ccc DNA from Streptomyces lividans and Escherichia coli. Plasmid 12, 19-36.
Kieser, T. \& Melton, R. I. (1988). Plasmid pI J699, a multi-copy positive-selection vector for Streptomyces. Gene 65, 83-91.

Maniatis, T., Fritsch, E. F. \& Sambrook, J. (1982). Molecular Cloning - a Laboratory Manual. Cold Spring Harbor, NY: Cold Spring Harbor Laboratory.

Maurer, H. R. (1964). Disk-Elektrophorese: Theorie und Praxis der diskontinuierlichen Polyacrylamidgelelektrophorese. Berlin: Walter de Gruyter.

van Pée, K.-H. (1988). Molecular cloning and high-level expression of a bromoperoxidase gene from Streptomyces aureofaciens Tü24. J Bacteriol 170, 5890-5894.

van Pée, K.-H., Sury, G. \& Lingens, F. (1987). Purification and properties of a nonheme bromoperoxidase from Streptomyces aureofaciens. Biol Chem Hoppe-Seyler 368, 1225-1232.

Pfeifer, O., Pelletier, I., Altenbuchner, J. \& van Pée, K.-H. (1992). Molecular cloning and sequencing of a non-haem bromoperoxidase gene from Streptomyces aureofaciens A TCC 10762. J Gen Microbiol 138, 1123-1131.

Sanger, F., Nicklen, S. \& Coulson, A. R. (1977). DNA sequencing with chain-termination inhibitors. Proc Natl Acad Sci USA 74, 5463-5467.

Schagger, H. \& von Jagow, G. (1987). Tricine-sodium dodecyl sulfate-polyacrylamide gel electrophoresis for the separation of proteins in the range from 1 to $100 \mathrm{kDa}$. Anal Biochem 166, 368-379.

Sedlmeier, R. \& Altenbuchner, J. (1992). Cloning and DNA sequence analysis of the mercury resistance genes of Streptomyces lividans. Mol \& Gen Genet 236, 76-85.

Sobek, H., Haag, T., Pfeifer, O., Schomburg, D., Lingens, F. \& van Pée, K.-H. (1991). Crystallization and preliminary X-ray data of bromoperoxidase from Streptomyces aureofaciens ATCC 10762. J Mol Biol 221, 35-37.

Tautz, D. \& Renz, M. (1983). An optimized freeze-squeeze method for the recovery of DNA fragments from agarose gels. Anal Biochem 132, 14-19.

Ward, J. M., Janssen, G. R., Kieser, T., Bibb, M. J., Buttner, M. J. \& Bibb, M. J. (1986). Construction and characterization of a series of multi-copy promoter-probe plasmid vectors for Streptomyces using the aminoglycoside phosphotransferase gene from $\operatorname{Tn} 5$ as indicator. Mol \& Gen Genet 203, 468-478.

Weng, M., Pfeifer, O., Krauss, S., Lingens, F. \& van Pée, K.-H. (1991). Purification, characterization and comparison of two nonhaem bromoperoxidases from Streptomyces aureofaciens ATCC 10762. $J$ Gen Microbiol 137, 2539-2546.

Wiesner, W., van Pée, K.-H. \& Lingens, F. (1986). Detection of a new chloroperoxidase in Pseudomonas pyrrocinia. FEBS Lett 209, 321-324.

Wiesner, W., van Pée, K.-H. \& Lingens, F. (1988). Purification and characterization of a novel bacterial non-heme chloroperoxidase from Pseudomonas pyrrocinia. J Biol Chem 263, 13725-13732.

Wolfframm, C., Lingens, F., Mutzel, R. \& van Pée, K.-H. (1993). Chloroperoxidase-encoding gene from Pseudomonas pyrrocinia: sequence, expression in heterologous hosts, and purification of the enzyme. Gene 130, 131-135.

Yanisch-Perron, C., Vieira, J. \& Messing, J. (1985). Improved M13 phage cloning vectors and host strains : nucleotide sequences of the M13mp18 and pUC19 vectors. Gene 33, 103-119.

Received 18 June 1993; revised 19 August 1993; accepted 24 September 1993. 